\title{
Student Representation of Mass Media as Tool for Forming Public Opinion
}

\author{
Aida V. Kiryakova ${ }^{\text {* }}$ \\ (iD) 0000-0001-6289-3797 SC 55932688800 E E-9040-2015 \\ Vadim V. Kolga ${ }^{2}$ \\ (i) 0000-0003-1195-1541 SC 57189985487 DAA-9754-2020
}

Andrey S. Yumatov ${ }^{3}$

(D) 0000-0001-5258-7016

Valentina P. Smorchkova 4

(D) 0000-0002-6123-9168 SC 57208034919 AAH-9499-2020

Elena N. Romanova 5

(iD) 0000-0001-5475-2193 AAF-9692-2019

Yury N. Tuganov ${ }^{6}$

(iD) 0000-0002-1206-0938

Vyacheslav I. Fedulov ${ }^{7}$

(iD) 0000-0002-3623-5245

${ }^{1}$ Department of the General and Professional Pedagogics, Orenburg State University, Orenburg, RUSSIA

2 Department of Economics and Management, Krasnoyarsk State Pedagogical University named after V.P. Astafieva, Krasnoyarsk, RUSSIA

3 Department of Organization Management, The Russian Presidential Academy of National Economy and Public Administration (RANEPA) (Orenburg Branch), Orenburg, RUSSIA

${ }^{4}$ Department of Pedagogy, Moscow State Regional University, Mytischi, RUSSIA

${ }^{5}$ Department of Foreign Languages and Professional Communication, Vladimir State University named after Alexander Grigoryevich and Nikolay Grigoryevich Stoletov, Vladimir, RUSSIA

${ }^{6}$ Justice Research Center, Russian State University of Justice, Moscow, RUSSIA

7 Department of Legal Regulation of Economic Activity, Financial University under the Government of the Russian Federation, Moscow, RUSSIA

${ }^{*}$ Corresponding author: gaida@gmail.com

Citation: Kiryakova, A. V., Kolga, V. V., Yumatov, A. S., Smorchkova, V. P., Romanova, E. N., Tuganov, Y. N., \& Fedulov, V. I. (2020). Student Representation of Mass Media as Tool for Forming Public Opinion. Online Journal of Communication and Media Technologies, 10(3), e202013. https://doi.org/10.29333/ojcmt/7934

ARTICLE INFO

Received: 16 Nov 2019

Accepted: 16 Mar 2020

\section{ABSTRACT}

The relevance of this article is to study the role of mass media and the extent of their impact on public consciousness, since almost every home has a TV, which is the most accessible way to communicate with the outside world and a means of obtaining information. The strengthening of modern mass media role, especially the Internet and television, in modern society is obvious, since information TV programs are aimed primarily at rapid, regular information about events in domestic and international life; in this regard, the most acute question is about the media as a tool for forming public opinion. The purpose of the study is to analyze students' perceptions of the mass media as a tool for forming public opinion and students' attitude to technologies for forming public opinion regarding the production of competitive import-substituting goods and services using the mass media. Research methods: as a research method, we used content analysis of TV shows, which allows us to identify in news: what events were broadcasted, what they said, how and in what context; as well as the interview method, which allows us to identify students' perception of the media as a tool for forming public opinion and determine the degree 
of impact of messages contained in the media on public opinion according to students. Results of the research: the article defines the students' perception of the mass media as a tool for forming public opinion. Verbal forms of presentation of information in television programs, which raised the topic of the production of competitive import-substituting goods and services, their application in various sectors of the economy are defined the rhetoric of news programs on the topics studied is described. It is revealed that these mass media use various information technologies: archetypes, images of folklore, designed to create a positive image of the production process of competitive import-substituting goods and services, the Russian product, and vice versa, a negative image of Europe and the United States. It is revealed that in news programs, the introduction of Western sanctions against Russia is often presented as a positive factor, although the negative impact is also presented quite significantly. It is shown that, according to the students, after the introduction of the food embargo, import substitution programs were introduced for goods produced within the country, which led to new opportunities and development of the potential of Russian citizens. It is determined that students see the role of television as ideological rather than informational. Students allocate the following tools for influencing public consciousness: emotional impact, suggestion, transfer of the private into the General, the use of rumors, the method of using frightening moments, silencing facts.

Keywords: student youth, public consciousness, information technologies

\section{INTRODUCTION}

Modernity is characterized by increasing scientific interest in the problems of forming public consciousness. (Adamjants, 1998; Etman et al., 1998; Makarova et al., 2019; Molchanova, 2005; Nazarov, 2003; Pocheptsov, 1998). It is well known that communication is one of the foundations of social life, which allows a person to form a worldview and get an idea of the society in which he/she lives, allows him/her to expand the communication of a person with a person, regardless of the distance and boundaries (Orekhovskaya et al., 2019; Pocheptsov, 2000; Sappak, 2007; Zasursky, 2002). Now, television broadcasting is able to reach the broadest segments of the population (the ability of television is explained by the peculiarities of its physical nature, which determines its specificity as a means of creating and transmitting a message), even those that remain outside the influence of the Internet, radio and print media. The most important tool for forming public opinion is the mass communication media, which use various techniques when forming public opinion, which later does not do without misinformation and manipulation (Kara-Murza, 2000; Sherkovin, 1975; Vasilik, Vershinin, \& Kozyreva, 2000). In the same way, the mass media, agitating and propagandizing, affect the public consciousness, and the individual consciousness is under psychological pressure, which is designed for the unconscious perception and assimilation of certain goals and values by citizens, forcibly imposing preprogrammed assessments and attitudes (Kovler, 1993).

Currently, the main channel for forming public opinion is television. Its specificity determines all types of features of programs, both publicist, artistic, and scientific and political (Demidov, 1992; Gerasimov, 1994). Television is a powerful means of manipulating the masses, which creates public opinion, forms political likes and dislikes. Television has a huge advantage, such as visuals. Now, television is used for hidden control of people's consciousness and behavior, and it is used in such a way that people's actions occur against their own interests (Cherdymova et al., 2019; Faleeva et al., 2017; Pocheptsov, 1998; Tsabolova et al., 2019).

Public opinion is one of the key categories in the conceptual apparatus of various scientific fields: psychology, political science, sociology, and journalism. Therefore, despite the complexity of its comprehensive analysis, researchers continue to study it (Boikov, 1990; Gavra, 1995; Kvon et al., 2017; Safarov, 1982; Zhitenev, 1987). Economic, social, environmental, political, ideological, and moral relations are the system in which public consciousness exists. The development of public consciousness is currently an independent industry aimed at forming an assessment opinion and attitudes using organizational and technical systems that ensure the rapid transmission of verbal, figurative and musical information (Baranov et al., 2019; Ivanov, 1993; Narutto et al., 2019). Most scientists distinguish the following properties of public opinion: scale (scope); subjective prevalence; polarity (direction); polarization; prevalence (social and geographical area); intensity; stability; speed of formation; coherence (consistency), etc. (Noel-Neumann, 1996; Parsons, 2002; Uledov, 1963). The formation of public opinion, thus, can be both spontaneous and conscious; the main characteristic feature of public consciousness in various scientific theories reflects the 
fact that this concept is a reflection of group value judgments on events, phenomena and facts. This point allows us to take into account the General patterns of formation of public consciousness, which are reflected in its characteristics, structure and mechanisms of formation.

\section{MATERIALS AND METHODS}

The attitude of students to the technologies of forming public opinion through the media was studied using a questionnaire survey, which consisted of the following questions:

- What TV news programs do you watch?

- Have you paid attention to topics related to the production of competitive import-substituting goods and services?

- How often do you encounter this topic?

- Is there a special presentation of this material in the media?

- How do you think these topics are covered? Are they sufficiently voluminous and bright?

- How do you think sanctions affect the Russian economy?

When using content analysis, several units are used to investigate this issue:

- The number of news releases that raise the topic of producing competitive import-substituting goods and services;

- The nature of the positioning of sanctions in news programs in terms of their impact on Russia and Europe;

- Representation of expert opinion related to the production of competitive import-substituting goods and services and sanctions in news programs included in the sample;

- The rhetoric of news programs regarding the topics being studied;

- Verbal forms of information presentation.

Categories in the issues, that is, determining that this is the right topic, were determined primarily in the announcement of the program in the headings, as well as by the first words of the TV presenter. The share of news releases that raised the issue of the production of competitive import-substituting goods and services will be fifty percent of the total number of issues for two years, that is, it was in every second issue on average. The nature of the positioning of sanctions and the production of competitive import-substituting goods and services in news programs, in terms of their impact on Russia and Europe, is presented in equal shares, that is, both positive and negative sides for Russia and Europe are shown. Expert opinion is present in every issue of news programs included in the sample.

The pilot study revealed that in the rhetoric of news programs, various information technologies are used to construct ideas about the production of competitive import-substituting goods and services, in particular, archetypes, images of folklore, which are designed to create a positive image of the import substitution process, the Russian product, and Vice versa, a negative image of Europe and the United States. According to the results of the study, we can say that this topic of sanctions, embargoes and import substitution with goods produced within the country is quite important for our country and the state.

\section{RESULTS}

Data analysis shows a low representation of reports related to the production of competitive importsubstituting goods and services (6\%), and a share of reports on the topic of sanctions is slightly higher (13\%) from the total broadcasting time of news programs included in the sample. The analysis showed that in the opinion of students (71\%), such topical issues as sanctions and import substitution with goods produced within Russia were not sufficiently and vividly covered. Despite the fact that these topics are very important for the domestic policy of the country, but the media attention to them is low. From the point of view of the majority of students (79\%) it can be connected either using the technique of silence, not to update the issue in the minds of citizens, with a decrease of interest among viewers to the themes and the appearance of higher ranked and popular topics, such as some problems of international relations. The content analysis also 
revealed the dynamics of the topic of sanctions in news programs, which in 2016 was almost 30\%, in 2017, it was $24 \%$, and in 2018 , it was $15 \%$. The survey of students' opinions showed that this topic was presented more than others were in news programs, according to students, and was the most relevant and discussed (79\%). The results of the study show the dynamics of the topic of the embargo in news programs: in 2017, it was $6 \%$ of the total broadcasting time, and in 2018 , it was $3 \%$. The analysis showed that this topic was covered the least in news programs, despite the fact that it is of great importance for the country as a whole. According to the students, after the introduction of the food embargo, import substitution programs were introduced for goods produced within the country, which led to new opportunities and development of the potential of Russian citizens.

The results of the study show that in news programs, the introduction of Western sanctions against Russia is often presented as a positive factor (61\%), although the negative impact (32\%) is also represented quite significantly. In addition, as a result, the student audience as a whole has a positive attitude to the imposed sanctions, because the domestic industry has become better developed and more opportunities have appeared for the domestic manufacturer. What cannot be said about the impact of European sanctions against Russia on Europe itself, where the positive impact is only $24 \%$, and the negative $69 \%$. On the one hand, the significant economic losses of the EU countries are highlighted, and on the other hand, the positive influence of sanctions on the Russian economy, the emergence of new opportunities are shown. The results of the analysis show that, according to students, the majority of reportages related to the topic of import substitution in one way or another speak about the impact of sanctions on Russia and Europe (69\%), tools for forming public opinion, since it is perceived as evidence showing how it really is. The students surveyed note that despite the fact that the impact of sanctions on the Russian Federation is presented in a verbal form both positive and negative, however, the video material constructs an image of an exceptionally favorable impact on the Russian economy and the common consumer (82\%). Students show a positive attitude to the imposed sanctions in more than half of the responses. The reverse is the situation in case with its influence on Europe (67\%). A qualitative analysis of the students' statements about their attitude to the reportages on sanctions, embargoes, and substitution of imports with goods produced inside the country show that since the beginning of the sanctions against Russia, the President has been diligently trying to reach agreements through peaceful diplomacy, but in the end, Russia imposed a food embargo as a response to the non-partner behavior of European colleagues. Another idea that is actively present in the statements of students is that the EU countries have suffered significantly and suffered economic losses because of the imposition of sanctions and US pressure. The following are phrases and statements that, in the opinion of students, create an image of a high-quality Russian product. To do this, we use words that refer to territorial, national, or ethnic identity. The following words were identified using content analysis: own, native, marked ours, natural, Russian. Elements of folklore, a positive attitude to paternalistic ideas in the mass consciousness, and a sense of national pride are also used.

Thus, we can conclude that, according to students (56\%), at the moment, the media really widely practice and use methods of subconscious influence on society, such as: the method of semantic manipulation, the method of distraction, the method of forming stereotypes, when the idea of the world is formed using stereotypes embedded in news streams, which in the minds of the masses automatically cause a positive or negative reaction to specific events, in fact, as it is shown above in the examples. The media also form the internal readiness of the particular student audience to perceive an object or a scene of reality in a certain way, changing not only people's minds, but also their attitudes (the term is due to the importance for humans of a specific item or action that are evaluated as good or bad; useful or harmful, and the like), and their structural components (affective, cognitive, conative).

\section{DISCUSSIONS}

The public consciousness is strongly influenced by the mass media, which is often referred to as the fourth power. The presence of public opinion can be observed in all branches of public life. Neither the political, social, economic, nor the environmental spheres can do without it. Current topics, issues and questions are becoming popular and arouse public interest. Discussions, talk shows, information shows, and so on are held on these topics. 
Influencing public opinion is one of the leading functions of the media. The state mass media is an important component of the state information policy. An essential task for the entire mass media system is to select the most important information, which, as a result, opens up wide opportunities for influencing public consciousness. Among the goals of the mass media are reducing the cost and making the process of promoting information in which the government is interested more effective. Information and analytical programs are also an important component of the state information policy, but not all news distributed by the media (for example, weather forecasts, music, sports, and other similar messages) are of a political nature. Political information includes information that is of public importance; knowledge that requires the attention of public authorities or has an impact on them. Based on the information received, citizens form an opinion about the activities of the government, Parliament, parties and other political institutions, as well as about the economic, environmental, cultural and other life of society.

Evaluation information in the representation of an event on the broadcasting time, including through emotional destabilization of the audience, as a way to change the scale of the event, is a manipulation of public consciousness, in which the actions of the Communicator, covered by the formal objectivity of the fact, are aimed at developing a certain social attitude and its structural components. Information confrontation in the communication space takes either open or veiled forms, the purpose of which is to change the reactions of the recipient of information, his/her self-esteem and directions of vectors of his/her value orientation, followed by a change in his/her behavior strategy based on adjusting the significance of news, since strengthening or weakening its importance is most easily carried out on the TV screen, where it is possible to fully use the entire Arsenal of audio-visual means available to modern television (Arutyunova, 2003).

Thus, the mass media perform the functions of everyday formation of public consciousness, daily orientation of the individual, which is certainly in demand in modern science.

\section{CONCLUSION}

Since about the middle of the twentieth century, we have witnessed and often participated in changes in socio-cultural reality under the influence of radical transformations in the field of information and communication technologies. These changes have affected many areas of society, leading to the transformation of the usual channels of communication and the creation of new ones. From the point of view of leading scientists, public opinion is a structural component of public consciousness, and most politicians have noticed television as an instrument of information management of public consciousness, as an arena of information confrontation. In the process of considering this issue, it can also be seen that if information important to the audience is supported by some events, it gets the status of official in the eyes of the audience, and the image of the event as a unit of information flow becomes an element of forming an idea of reality, due to the lack of the recipient's own experience with the phenomena raised by the media; television information anchors the audience's social attitudes in the way that it is seen by the influencers themselves, while not allowing listeners to objectively present their vision of the picture. The main problems are revealed by the mass media in the news of the day, which determine the hierarchy of events in the holistic image of reality created by the authors, unfolding the daily canvas of reality as a form of political theater.

Each medium of mass communication (radio, television, Internet) has its own advantages and properties that allow you to effectively perform certain socio-political functions in the process of forming public opinion. However, neither the media, nor journalists, should exercise that fourth power. It should be represented by public opinion, which is formed by the society itself and its socio-political structures, expressed through mass media, including traditional ones. Among the methods of forming and managing public opinion, one can distinguish the method of semantic manipulation; the method of distraction; the formation of stereotypes; and the image being created. The messages themselves in the media can be presented in both emotional and dramatic forms, while the mechanism of creating a common enemy is often used to create a negative public reaction; only negative features are drawn, and positive information is suppressed. As a result, information messages, as elements of suggestion, can be submitted at any time in any context. Thus, it can be assumed that each method has a targeted impact, so it is difficult to determine which one will be most effective. For example, mass communication media can influence political or environmental consciousness by influencing the information that allows reflecting real facts and in a certain way form mass consciousness, where certain 
stages of the information process are highlighted (obtaining information, selecting it, analyzing and synthesizing it and further dissemination of information).

\section{REFERENCES}

Adamjants, T. Z. (1998). Telecommunications in the social design of the information environment: Diss. Of PhD. Moscow, $224 \mathrm{p}$.

Arutyunova, N. V. (2003). The Image of reality on the TV screen and the electoral process: Experience of polit. analysis. Moscow: Socium publishing house.

Baranov, V. V., Cherdymova, E. I., Novikov, S. B., Lukina, E. V., Kazurov, O. A., Korzhanova, A. A., \& Gurbanov, R. A. (2019). Student attitude to ethical consumption as new ecological practice. Humanities \& Social Sciences Reviews, 7(4), 1173-1179. https://doi.org/10.18510/hssr.2019.74160

Boikov, V. E. (1990). Social consciousness and perestroika. Moscow: Politizdat publishing house.

Cherdymova, E. I, Faleeva, L. V., Ilkevich, N. G., Sharonov, I. A., Sayfutdinova, G. B., Leusenko, I. V., \& Popova, O. V. (2019). Socio-Psychological Factors that Contribute to and Impede the Process of Student EcoVocational Consciousness Formation. Ekoloji, 28(107), 133-140.

Demidov, A. M. (1992). Public opinion in the way of institutionalization. Sociological research, 2, 75-78.

Etman, R., Reid, D., Mickiewicz, E., \& Firestone, Ch. (1998). Television, radio and privatization: issues of advertisement property and progressive politics in the changing market of mass media. Moscow: LIVR publishing house.

Faleeva, L. V., Bratukhina, E. V., Ezhov, S. G., Gorbunova, L. N., Lopanova, A. P., Viaznikova, L. F., \& Kryukova, N. I. (2017). Student's social experience forming in university vocational training. Eurasian Journal of Analytical Chemistry, 12(7), 1127-1135. https://doi.org/10.12973/ejac.2017.00238a

Gavra, D. P. (1995). Public opinion as a sociological category and as a social institution. St. Petersburg: ISEP.

Gerasimov, A. B. (1994). Public opinion and military policy (political analysis): Diss. Of PhD. Moscow.

Ivanov, O. I. (1993). Public opinion and power. Social and political journal, 7, 35-44.

Kara-Murza, S. G. (2000). Manipulation of consciousness. Moscow: Algorithm publishing house.

Kovler, A. I. (1993). Fundamentals of political marketing. Moscow: Rudomino publishing House.

Kvon, G. M., Faleeva, L. V., Pyrkova, G. K., Alyakina, D. P., Mustafina, A. A., Kryukova, N. I., \& Blekus, V. V. (2017). Strategic Priorities of Regional Investment Activity. Eurasian Journal of Analytical Chemistry, 12(7B), 10991106. https://doi.org/10.12973/ejac.2017.00235a

Makarova, E. V., Kryukova, N. I., Sizova, Z. M., Grinenko, A. V., Erofeeva, M. A., \& Bukalerova, L. A. (2019). Divergence of Supreme Values of Russian World and Western Civilization Social and Philosophical Analysis. European Journal of Science and Theology, 15(3), 97-107.

Molchanova, E. H. (2005). Television in the culture of the modern information society (dis. of PhD in Philosophy). Stavropol: Stavropol state university.

Narutto, S. V., Cherdymova, E. I., Sokolova, E. D., Savostyanova, S. A., Stolyarova, A. N., Vilskaya, N. V., Konovalova, I. A., \& Smirnova, E. A. (2019). First-Year Student Attitude to Social Networks. International Journal of Applied Exercise Physiology, 8(2), 273-276.

Nazarov, M. M. (2003). Mass communication and society. Introduction to the theory of the study. Moscow: Avanti plus publishing house.

Noel-Neumann, E. (1996). Public opinion. Opening the spiral of silence. Moscow: Progress-Academy publishing house, the Whole World.

Orekhovskaya, N. A., Chistyakov, A. A., Kryukova, N. I., Krokhina, J. A., Ospennikov, Y. V., \& Makarova, E. V. (2019). Orthodoxy and modernity their contact facets in Russian society. European Journal of Science and Theology, 15(2), 67-77.

Parsons, T. (2002). On the structure of social action. Moscow: Academic project publishing house.

Pocheptsov, G. G. (1998). Public relations or how to successfully manage public opinion. Moscow: Center publishing house.

Pocheptsov, G. G. (2000). Communication technologies of the twentieth century. Moscow: Refl-Book publishing house, Wakler.

Safarov, R. A. (1982). Public opinion in the system of Soviet democracy. Moscow: Znanie.

Sappak, B. C. (2007). Television and us: four conversations. Moscow: Aspect-Press publishing house. 
Sherkovin, J. A. (1975). Psychological problems of mass information processes. Moscow: Mysl publishing house. Tsabolova, O. R., Cherdymova, E. I., Ilyin, A. N., Zhukova, M.A., Tsopanova, I. G., Krasnova, L. N., Mashkin, N. A., \& Bugaeva, T. K. (2019). Ecology of psycho-emotional climate in labor collectives: Factors, problems and prospects of development. EurAsian Journal of BioSciences Eurasia J Biosci, 13, 2027-2032.

Uledov, A. K. (1963). Public opinion of the Soviet society. Moscow: Sotsekgiz.

Vasilik, M. A., Vershinin, M. S., \& Kozyreva, L. D. (2000). Public relations in Russia: organizations and documents. St. Petersburg: Publishing house of SPb. state tech. university.

Zasursky, Ya. N. (2002). Mass media of post-Soviet Russia: Handbook for University students studying in the field and specialty Journalism. Moscow: Aspect-press publishing house.

Zhitenev, V. B. (1987). Public opinion in social management. Novosibirsk: Nauka.

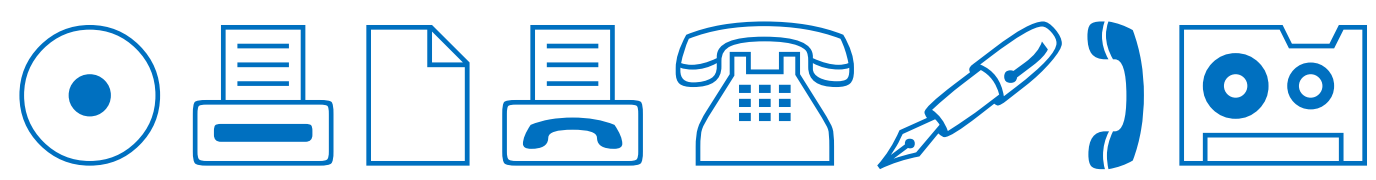

